This item was submitted to Loughborough's Research Repository by the author.

Items in Figshare are protected by copyright, with all rights reserved, unless otherwise indicated.

\title{
Organizing masculine bodies in rugby league football: groomed to fail
}

PLEASE CITE THE PUBLISHED VERSION

http://dx.doi.org/10.1177/1350508413517409

PUBLISHER

SAGE Publications / @ The Author

VERSION

AM (Accepted Manuscript)

\section{PUBLISHER STATEMENT}

This work is made available according to the conditions of the Creative Commons Attribution-NonCommercialNoDerivatives 4.0 International (CC BY-NC-ND 4.0) licence. Full details of this licence are available at: https://creativecommons.org/licenses/by-nc-nd/4.0/

\section{LICENCE}

CC BY-NC-ND 4.0

\section{REPOSITORY RECORD}

Coupland, Christine. 2014. "Organizing Masculine Bodies in Rugby League Football: Groomed to Fail”. Loughborough University. https://hdl.handle.net/2134/16708. 


\title{
Organizing masculine bodies in rugby league football: Groomed to fail
}

\section{Christine Coupland}

\section{C.Coupland@lboro.ac.uk}

\section{Online first author accepted version for Organization Published online before print January 7, 2014, doi: 10.1177/1350508413517409}

\begin{abstract}
In the paper I argue that a study of high contact sports, such as rugby league, can illuminate a discursive space in which the production of organized, docile, masculine, bodies, engaged in emotional labour are crafted and mobilized through disciplinary practices. Participants from a rugby league football club and their trainers have been interviewed and observed as part of a larger ethnographic study. The analysis provides a contrast to and develops understanding from studies of the organized female body, which have long argued that they are subject to disciplinary forces in the workplace (e.g. Trethewey, 1999), by illustrating how masculine bodies may also be made docile in particular organizational contexts. The paper explores the organization of masculine bodies in professional sport as an example of the production of masculinity in a work environment. I conclude by suggesting that these masculine bodies are worked upon to be fit for organizational purpose in a similar way to how women's bodies are crafted to fit in male-dominated work environments. This is not simply through an imposition of more powerful ideologies but as simultaneous products and producers of the organized body. Furthermore, despite these efforts, the bodies become no longer fit for use with the passage of time. The erosion of ability due to injury and competition from younger, fitter, bodies ensure that their working lives are brought to an abrupt close.
\end{abstract}

\section{Keywords: Career, Masculine bodies, Organizing, Rugby League, Sport}

\section{Introduction}

The research is focused around how bodies become organized. In keeping with feminists' (in the main) arguments around bodies as being subject to the patriarchal gaze, the paper provides empirical development of the construction of masculinities. I propose that professional sports' careers are less like leisure and more like work (see Storey 'This Sporting Life' (1960) for an accessible account of rugby league). This is demonstrated in the study as; performance is publically measured, penalties occur if ability fades, routines and practices are determined by others and contracts of employment depend on performance. Thus, it is argued that sport as work provides a context in which to consider; a) how bodies become organized, b) how masculinity is constructed by degree, c) the feminization of masculinity in this hypermasculine context, and d) how males are subject to the patriarchal gaze. That said it is not a body with a purposeful, thinking, mind that is being separated out for examination, rather an embodied set of practices, which are conjoined and carried out by a number of individuals, described in the research and thus made sensible to another audience. It is argued that the embodiment of this work activity is a socially accomplished task, which is also made visible in articulations.

The professional sports club selected for investigation is a rugby league club based in a Northern city in the UK, given a pseudonym for the research 'Northern Knights'. 
Previous studies of rugby have described it as a 'sport of violence' (Pringle, 2001: 425), a professional contact sport with a propensity for significant injury (Howe, 2001) and viewed as an ideal vehicle for instilling manliness (Gray, 1983: 29). Thus it is a full body sport with a high premium placed on physical force. At the time of the study Northern Knights were playing in the Super League, the top division for rugby league in the UK. In contrast to professional football teams rugby players have a fairly recent history of playing at semi-professional level. The fissure between rugby league and rugby union in the UK came about where (predominantly Northern) players were given 'boot money' as they missed paid work in order to play. This caused a break away from the traditional amateur status of the game and two different sets of rules of play emerged. Although both rugby union and rugby league are professional sports now, the demarcation lines still exist today roughly along a north/south divide (with exceptions). This has implications for the size of the gate and the potential of being a self-funded organization (arguably there is more disposable income in the south). There is a class issue here too which emanates from the historical context that sees rugby league being played initially in heavy industrial working class areas, e.g. coal mining areas or the docklands. It is acknowledged that social systems such as race, gender and class interlock to both oppress and provide resource for identification - social belonging (Ezzell, 2009; West and Fenstermaker, 1995), hence, the sport of rugby and rugby league specifically has a particular, harder, style of masculinity that also speaks to class differences. Again, in contrast to football, income generated through rugby is much lower and is subject to wage-capping which means that players' salaries and the business potential of the sport are reduced. Thus, this is a professional sport which is constrained financially and is supported through the altruism of local benefactors and the loyalty of the fans. Club contracts for first team players are typically for three years, but these may be extended for one year at a time. The contract can be ended by the club at any time based on performance issues on or off the pitch. Playing careers are short, although first team members as young as 16 are not unusual. At the level of Super League it would be rare to find a player still playing regularly beyond his mid-thirties.

Body and work and body commodification have attracted growing interest from organization theory scholars. Although much research has emerged from within host disciplines of sociology, anthropology and psychology the work context and worker relationship is increasingly a site of investigation. Kolkowitz (2006), for example, approached a number of issues around bodies at work from a sociological perspective. Scheper-Hughes and Wacquant (2002) presented an edited collection which included an anthropological approach to commodified bodies as both objects and semi-magical and symbolic representations - heavy with meanings and significations (p2). And Durand and Hatzfield (2003) wrote of an ethnographic study of embodied work on a car assembly line. In addition, there has been research within traditional work environments where gendered body work has been explored and a growing number of articles point to the value of considering forms of gender within specific sites of gender construction. For example, Mills (1998) looked at multiple masculinities among the employees of an airline company; Trethewey $(1999 ; 2000)$ presented studies of bodily control among employees. Linstead (1995) also considered the airline industry as a site of resistance to bodily constraint and patriarchal gaze. Furthermore, Connell (2000) has made the connection between work and sport as arenas in which masculinities are enacted and makes an 
important point that institutions of competitive sport seem peculiarly important for contemporary Western masculinities (p11). Thus, it is argued in a research context where gender is predominantly male this enables (or requires) degrees of masculinity to be enacted and is therefore of interest to organization scholars more generally. In the context of the study the unworked-upon body is regarded as weak and ripe for transformation to the more powerful, hyper-masculine, athletic, body required for the job, in order to be picked to play. Arguably, therefore, the male body is feminized (not to suggest a fixed, binary, gender relationship, rather as a lessthan-exemplary male sports-body) prior to the organizing intervention of the routines of practice that produce; the docile, yet appropriately aggressive, deferential, yet hyper-male, worker. This is interesting and worthy of exploration for three reasons. First, it resonates with and expands upon the findings from studies of female workers in male dominated environments in that gender is enacted under the gaze of a judgemental other. Second, fierce competition to be picked to play each week renders the rugby player a willing participant in this organizing process. Third, despite efforts to craft the appropriate athletic, yet emotionally deferential, embodied, performance the very work itself is bringing the end of the career closer due to the damaging potential of the performance on the pitch.

The contribution of the paper includes an understanding of how body-work operates as a conjoined effort by members of an organization on members of an organization. The role of organized and ritualistic performances of and on these bodies in pursuit of both disciplined docility and emotionally controlled labour is therefore explored. These discussions are situated within the backdrop of both Foucault's and Bourdieu's considerations of bodily metaphors of fixity and fluidity. In summary, the paper seeks to; extend empirical understanding of the male worker body, demonstrate how masculinities are constructed around a worked-upon, disciplined, male body and illustrate that the worker, through his craft, ultimately renders his body no longer fit for purpose.

\section{Theorizing the organized body}

The paper draws upon two key theorists whose work has been useful for understanding aspects of organizing. First, in keeping with Foucault's arguments on the body, discourse and discipline $(1976 ; 1977 ; 1984)$ it is considered how this work illustrates the participants' body work as subject to regimens of control. Second, Bourdieu's $(1977 ; 1984 ; 1990)$ concept of the body as a form of capital is useful in order to understand how the practices of the social world shape the deployment of the worked-upon body. Both Foucault and Bourdieu provide an analysis of social control through embodiment. Rugby is an intensely physical game, the player enters a 'body centred universe' (Wacquant, 1995 p66) when working at a professional level. In the same way that a boxer is his body (Oates, 1987) a professional rugby player's body is the medium and the outcome of effort.

Rugby league is an example of a contact sport in which the male athletes typically accept the notion that real men endure pain and injury (Roderick et al, 2000). The use of violence and the tolerance of pain are viewed by their participants as masculinising (White et al, 1994). Bourdieu's notion of socially relevant fixings of embodiment and Foucault's notion of disciplined bodies both work to explain these kinds of historically located themes of embodied fixity, however, they do not provide for a capacity of fluidity or paradox. This is a study of, within the contested terrain of 
masculinities, how the male body is subject to disciplinary practices which have material consequences by inscribing gendered ideals of hyper-masculinity onto the male bodies. However, it has been argued that rugby, although described as a 'sport of violence', provides a discursive space for the production of and resistance to dominant discourses of manliness (Pringle, 2001). It is proposed, therefore, that men and masculinity have to be theorized as both structured in dominance and active in reproducing that dominance (Edley and Wetherell, 1996), thus it is claimed that intransigence is not the complete story of the diverse forms of bodily being in the world. Questions can be raised regarding the extent of bodily discipline as an organizing process even in a hyper-male work environment.

It has been argued that research which tends to privilege theorising has not paid sufficient attention to specific social contexts in which embodied practices occur, thus ignoring relevant practical experiences of embodiment (Watson, 2000). The purpose of the study is to illuminate the embodiment practices of organized male workers through a study of professional rugby players and their trainers. This provides an opportunity to develop a more empirically grounded understanding of how bodies are organized. Organized bodies have, in the main, been studied from the perspective of gender (e.g. Trethewey, 1999; 2000; Godfrey et al, 2012; Haynes, 2012). Women's bodies particularly have been studied as sources of organizational value-added through offering forms of embodied capital (e.g. Brewis and Linstead, 2000). It is timely then to consider the male body as an instrument and outcome of (bodily) production through organized transformation processes.

Bourdieu's concepts of habitus and cultural capital are relevant as theoretical schema in terms of explaining broader relationships between the embodied self and the organized individual (Wacquant, 1995; Wainwright and Turner, 2006). There is much debate around to what extent 'habitus' reproduces social order on the one hand and how it may be a useful concept for opening up possibilities for theorizing change as an alternative view (McLeod, 2005). Recent feminist analysis attends to this debate and questions Bourdieu's attribution of durability to gender norms, some arguing instead for recognition of the instability of gender norms (McNay, 2000). In keeping with this argument, I suggest that there is both instability and durability within gender enactments. Wacquant's convincing argument of habitus as a concept to consider embodiment proposed that "habitus is a guide for probing the springs of social conduct" and thus offers a powerful tool to steer social inquiry (2011: 82). As a demonstration of the theory's utility Bourdieu's analytical framework has been closely applied to other studies of the use of the body (e.g. Daly, 1995; Klinenberg, 2002; Morris, 2001; Wacquant, 1995; 2004; 2011 and Kolkowitz, 2006). According to Bourdieu behaviour is not determined by this system, but it provides a practical sense that inclines us towards one way of being rather than another. Social relationships create habitus which is expressed in everyday contexts, beliefs which order our behaviour are not states of mind but states of body where the body is a living memory pad operating through practical metaphors (Bourdieu, 1990). Thus, it can be argued that the body is a site of incorporated history (Thompson, 1991), displayed through body shape, gait and posture. It follows, therefore, that sport, or rugby training specifically, produces a particular type of body with mastery over particular kinds of movement which is socially produced through diet, exercise and etiquette. The detailed study of the members of one organization enabled us to recognise elements of this body-work as socially organized and mundane practices. 
Bourdieu's concept of habitus illuminates a circular process whereby practices incorporated into the body are regenerated through embodied work (Crossley 2001). It can be argued that traces of physical capital are converted into economic capital through sport or training for sport, or other physical endeavours, called bodily capital (Wacquant, 1995). Those who are engaged in crafting this bodily capital into optimum playing capital (both those instigating training and those who carry it out) may be regarded as entrepreneurs in bodily capital. It is possible to produce value in terms of income and recognition on the pitch for the benefit of the individual, the club and the industry more broadly. Harman (2009) describes Marx's view of capitalism where capital represents 'dead' labour as an accumulation of surplus from living labour which seems to fit here where the labour process illustrates a spread of 'scientific management' techniques into professional sport (Braverman, 1974). As a means of production the player's body is worked upon to accentuate talent and body shape for the requirement of the game. However, one certainty of this process is its temporality - despite all best efforts the body will succumb to injury, wear and tear and an ageing process that renders the player unable to compete with younger, faster, stronger, bodies. The body will erode under physical pressures, thus rendering the opportunity to take entrepreneurial advantage from it short and likely to be curtailed rapidly in the event of severe injury. In Wacquant's (1995) ethnographic study of boxers in Chicago, he utilised Bourdieu's concepts and observed that objective structures of the social world of boxing became embodied in the boxers' habitus. In a similar way the rugby players are willing to sacrifice their carefully crafted and honed physical well-being to a body-damaging performance on the pitch without question.

Foucault's arguments on the body, discourse and discipline provide a framework from which to consider how articulations of body work are subject to regimens of control, as Foucault foregrounds the body as the arena in which discourses of power operate (Godfrey et al, 2012). In Foucault (1977) an argument is developed around how docile bodies are produced. He argues that disciplinary measures have always been in place upholding constraint, prohibition and obligation (p136). However, by treating the body at the level of the movement, gesture and attitude, through the 'ceremony' of exercise, processes of activity make possible the meticulous control of the body for purpose. That is, a docile utility - in contrast to slavery, service, vassalage or monastic discipline - through a manipulation of gesture and behaviour a more obedient and more useful body is produced. He makes the point that increased aptitude is linked to increased domination through a 'new' political anatomy. He concurs that 'new' implies sudden and clarifies this is not the case, its processual nature comes from multiple sources providing a blueprint of a general method (p138). What Foucault offers for the study is some attention to the importance of detail. The techniques of bodily control define detailed political investment in the body, thus, he argues, discipline is a political anatomy of detail (p139).

However, Foucault has been criticized for not providing sufficient account of the gendered nature of disciplinary techniques (Trethewey, 2000), that the body is both a product and a process and thus a locus of social control (Balsamo, 1996). I argue that, in the same way that women learn to discipline their bodies within contemporary regimes and practices of femininity (Young, 1990), the rugby player's body is subject to routines of exercise and other working on the body (e.g. regulated practices of abstinence), thus a colony of the self is methodically developed. This resonates with 
women's self-disciplinary practices around diet, comportment, makeup and dress, focusing on self-modification rather than social orientation (Bordo, 1989), in order to manage gender as a status in the context of a male-dominated environment. These arguments are developed and I propose that in the context of professional rugby players' work environments, where a hyper-masculine 'ideal' body is required, tensions emerge for the un-worked upon male body between expectations and the lived experience of their work.

\section{Methodology}

\section{Reading the sports context as an organized context}

The popularity and influence of sport in Western society render an exploration of its organization pertinent to scholars of organization studies. Organized sport was originally created for men and boys in the middle of the $19^{\text {th }}$ century (Messner, 2002). Although currently women and girls make up one third of sports' competitors (Knoppers and Anthonissen, 2005), it is an institution that is formally structured around gender, is based on physical achievements and thus highlights embodied performances as most relevant. As a context in which mental toughness, physical strength and top performance predominate in discourses which sustain particular forms of masculinity, it reflects to some extent desirable masculinities in other organized contexts, such as the boardroom, or the workplace (Coakley, 2004). Studies of male athletic and managerial masculinities have found congruence in their discourses and suggest future research in this area is required (Knoppers and Anthonissen, 2005). Thus an exploration of a culture where men predominate enables a timely study of how masculinities are created and reproduced.

\section{Methods}

The material used to support the arguments in the paper is taken from a larger study of a professional rugby club. The study took place over approximately one year, from the beginning of April 2011 to the end of May 2012. There were three key internally located groups of people (players, football staff and other organizational members) and one ostensibly externally located group (supporters). The football staff included; coaches and assistant coaches, nutritionist, sports psychologist, strength and conditioning coach, trainers and the football manager - all those club employees who have a direct impact on the players' performances. The other non-playing group of organizational members also has two sub-divisions; the Directors, who differ in their levels of engagement, some are employees, some are benefactors and some are more peripheral to the club; and the staff who run day-to-day operations typical of most organizations (e.g. media, advertising, finance, retail, community engagement). Players consist of: the first team; under 21s; the youth team and members of the academy. The material for this paper is taken from observations of and interactions with the players from the first team. This squad typically consists of around 23 contracted players, although during any season there will be unexpected departures and some arrivals as replacements.

Data collection took place in various forms throughout this period. The author would spend on average one day a week at the club, taking temporary residence in the football manager's office (where other trainers and players spent some time each day) and attended some matches and off-field events during the playing season. In addition to formal interviews with members of the club, (47 members were 
interviewed) much of the time was spent 'hanging around' (van Maanen, 2011) observing and noting the mundane, ritualistic and unusual occurrences of the organization. Training sessions were held by the football staff for the players each morning between 9.00am and 11.00am most days, followed by lunch and other training activities. I as researcher and author attended some of these and took up a position on the sidelines at some of the on-the-pitch training sessions waiting for individual meetings or interviews. By deliberately arriving 'early' I could legitimately be seen to be doing 'nothing' while observing and listening to the coach /football staff /player interactions on the field of play.

The material is thus made up of; formal, semi-structured, interviews with a range of members of the organization, overheard conversations and training interactions and author-interpretations of events and exchanges. Although a professional sports' club it operates as a medium sized organization with several similarities to the organizations which more usually attract the attention of scholars of organizational theory. The players perform in a similar way to creative or knowledge workers whose talents and abilities are harnessed for the benefit of the organization. The process of organizing includes working upon the members' talents (in the rugby players this includes their bodily capital) to optimise their performances. Thus the group of organization members most closely associated with this process (in the rugby club this would include, trainers, nutritionists and coaches) operate rather like craftspeople who work upon the raw material of the players' abilities and bodies. Their success is measured very closely through changes in players' body shape, speed, strength, agility, suppleness and stamina which translate into on the field performances.

It is noteworthy that the researcher is female and entered a masculine world as a 'stranger' with no desire or ability to fit in, or be part of the landscape. In a tightly organized community anyone would be seen and treated as a stranger. As an environment under intense scrutiny from outside by fans, the media and other sporting bodies it operates as a close-knit unit. Thus, there is no reason to speculate whether the research would produce different outcomes if the researcher were male - of course it would, but so too if the researcher was another female. While adopting a research perspective which claims multiple masculinities and femininities this too may be applied to the gendered research process. Every practice includes a gendered bodily process - including sociological research. As a female who has selected to enter and study a male world I claim an epistemic reflexivity (Bourdieu and Wacquant, 1992) and acknowledge that the research has been conducted from my worldview, my gendered enactments as a researcher appellate particular responses which have then been subjected to my particular analytic attention. This has unquestionably provided a particular perspective to the research and, in part, may explain why the notion of rugby players and their work as subject to similar disciplinary practices for women in male dominated environments came to the fore for the author and thus the paper.

\section{Rituals of disciplined bodies and rituals of emotional labour}

Rituals of disciplined bodies 
It is argued that disciplinary practices occur in this work context through both bodily and emotionally controlling processes.

In order to demonstrate the fixity of embodied activity as described by Bourdieu and Foucault I draw on and discuss some examples of processes and practices through which the un-worked upon male body is made useful for the required performance of a rugby player. The following sections of the paper include an examination of processes of (body) production that are brought about through ritualised body work. It is not surprising that rugby players' bodies are worked upon to make them more fit for purpose, this is not claimed as a finding of the study. Rather, how they are objectified and crafted upon as units of production by other members of the organization should be of interest - particularly as this organized set of disciplinary routines mirror processes that are more typically thought to occur around women's bodies.

The coaches talked about how the players were selected and made to work to improve their performance as a process of organizing the body to be fit for purpose.

we look at the human body and we tend to do a weight routine for anybody, first of all we'll test them and then we'll see if there's any weaknesses in any area, then when we actually do a template of their weight schedule which they'll go and do every, probably every day in preseason (Coach)

they might be weak in a certain part of their anatomy, it might be they might have weak glutes and that means when you're doing certain exercises they can't squat very well (Coach)

A practice of discipline, according to Foucault, is to control the activity of the body through detailed management of tasks assigned to it. Through exercise practices the body must learn to move in prescribed ways, called an 'instrumental coding' of the body (Foucault, $1977 \mathrm{p} \mathrm{152).} \mathrm{However,} \mathrm{this} \mathrm{is} \mathrm{not} \mathrm{simply} \mathrm{to} \mathrm{suggest} \mathrm{that} \mathrm{the} \mathrm{players}$ are unwillingly coerced into capitulating with these activities. Bourdieu's explanation of this process is through a notion of capital, including an embodied form, which is worked upon in a social context in which the participants appropriate social energy in the form of living labour (1986 p 241). In Wacquant's (1995) ethnographic study of boxers he argued that their whole existence was consumed by servicing, moulding and purposeful manipulation of the body (p66). The coach below explains some of the practices.

We also do a lot of running, we do a lot of strong man, which is pushing tyres, flipping tyres, jumping in and out of tyres, carrying tyres above your head, really tough horrible, and what we try and hit their what you call an energy system (Coach)

We try and make it as horrible as we can and so obviously we have them all being sick and puking up and crying and calling us all names, [laughs] we know if we can keep pushing it and pushing it, we know they're going to get fitter but also they're getting that mental toughness of actually being under pressure and what we've got to do is to push them to their limits mentally as well as physically, how much can you tolerate (Coach)

Foucault (1977) argued that a disciplined body should be subject to a precise series of measurements with activities broken down and repeated through the deployment of exercises. This is assumed to produce a disciplined (docile) body which must be worked upon to be kept docile. Ritual can have a profound impact on ordering behaviour, below are some examples of training instructions shouted to the players in training each day. 
The day starts with a timed circuit of the pitch every day in season

Push the power sled to the end of the pitch

Side-step squats, 3 sets of 15 repetitions

Flying sprint - Walk 10 meters, sprint 20 walk back to the beginning and repeat

Dead lifts - 4 sets of 12 repetitions (Detail from notes of observations)

Any potential lack of enthusiasm is punished with more rigorous activity:

Drop and give me 20 (push ups/sit ups/bench presses)

I have some tyres I need moving (this refers to the 'strong man' activities described above) (Detail from notes of observations)

Simple procedures such as hierarchical observation and normalising of judgements will be effective in producing a docile body (Foucault, 1977 p 170). Increasingly the use of technology to measure and control the rugby player's body plays a part in the disciplining process. A trainer/coach explains below.

We put them on the running machines and wire them up see how far they can go (Coach)

And the players refer to these systems as beneficial for their game.

Heart rate monitors and all that kind of stuff, it started to get, a lot deeper and technology and stuff and that does really benefit your game. (Player)

I wear a monitor (like a black bra) all the time in training - it collects lots of information for the trainers (Player)

In addition to the routinized training schedule, which focuses on general strengthening and fortification body work, the trainers discussed the minute detail of preparation of the players on a daily basis. This included repeated viewings and analysis of the match videos - both their own team and their forthcoming opponents. After a game the match was watched and dissected move by move and a postmortem focusing on errors and incapacities of the players to meet the required standards of performance was carefully carried out. One member of the support team was employed primarily to capture, record, retrieve and assist with the analysis of this material and then suggest player weaknesses requiring re-training as seen in the extract below. Decisions made regarding selection for the team were in part also based on this surveillance footage.

I video all the games and all the training sessions- is everything getting across is that affecting performance (Coach)

In this, highly public and visible, organization many venues to display organizational statistics are apparent. The club has a web site which incorporates a vast amount of material available for any member of the public and any other member of the organization to view and comment upon. One example of this display is in the production of the vital statistics of a player which are shown as 'bodily capital' on the club web site, an example is given below.

\begin{tabular}{l|l} 
Player Stats & \\
\hline Position & Outside Back \\
\hline Date of Birth & 15.01 .84 \\
\hline Place of Birth & Grangetown \\
\hline
\end{tabular}




\begin{tabular}{l|l} 
Height & $187 \mathrm{~cm}$ \\
\hline Weight & $95 \mathrm{~kg}$ \\
\hline Last season & \\
\hline 26 appearances & 20 tries scored \\
\hline \multicolumn{2}{l}{ (From Club Web Site) }
\end{tabular}

Rather like the 'tale of the tape' as the official valuation of fighters before a boxing match the detailed evaluation of each player includes measurements (e.g. age, height, weight) and performance (e.g. appearances and tries scored) so that the interested reader may evaluate the likely performance from the player, a calculation based upon physiological measurements and the 'refurbished, re-tooled, significantly restructured body as an instrument of production' (Wacquant, $1995 \mathrm{p} \mathrm{70).}$

The players are trained as a full squad each week but, subject to injuries, there are always more players in the fully trained first team squad than there are positions for a game. This means that there is fierce competition between the team members to be selected for as many weeks as possible. An example of constantly experienced hierarchical judgement as the coach and other training staff make judgements each week on who is likely to play based on performance and perceived readiness in training. An effective disciplining, or controlling, of the players for the entire season as tallies are kept of each player's performances both within the team and more widely circulated. Ultimately, and more broadly the player attains currency in terms of increasing the likelihood of being head-hunted for better teams- if he is given sufficient opportunity to display his ability. The opposite is also the case, as not being picked suggests increasing invisibility to the team and beyond. This is illustrated by the player's comment below.

for me that's just how it works, it's very, very black and white, the second you get on the training pitch and that you're in competition, you're, eventually you are trying to get a job (Player)

Thus it is demonstrated how the government of the body is a collective enterprise, where other organizational members are performing a potentially panoptical environment that subjects the player to surveillance. In Bourdieu's terms - a habitus and field for the maximum accumulation of bodily capital. Rigorous sports training provides a routinized, legitimated, set of practices that enable self-sacrifice and deprivation to become acceptable.

The role of the coach and others in terms of governing the rugby players' bodies is an important one from the first instance as they identify 'raw' material, in the extracts below, on which to work their craft and can 'recognise' appropriately featured bodies for their attention.

Looking for big giant of a man, must weigh about a hundred and twenty five kilo but you only get ten minutes out of it, not good enough (Coach)

Then you get your rhino body shape, nice, long lean broad shoulders, more of a four hundred metre sprinter he goes into seclusion he spends a lot of minutes on the pitch (Coach)

And a sense of being able to recognise an embodied attitude to the game more broadly as the useful body is not separated from the whole individual in the search for the right material.

Tough kids, give me thirteen tough human beings instead of thirteen athletes (Coach) 
It has been demonstrated in this section of analysis that rituals of discipline are drawn upon to bring about the docile body that has been worked upon to make it (more) fit for purpose. However, this docility is not just engendered in bodily performance, it is also applied in order to produce appropriate emotional performances too. This is discussed in the next section.

\section{Rituals of emotional labour}

It could be argued that rugby players' bodies are specifically and understandably developed to perform a task on the pitch. Their body shape, strength and stamina have a direct bearing on their performance on the pitch and therefore, arguably, of direct interest to those who employ them - they have bodily capital. However, Northern Knights' players also discussed how they were expected to perform, emotionally, beyond the game. This finding resonates with studies of women who work in occupations requiring appropriate facial expressions; e.g. flight attendants (Tyler and Abbott, 1998) and bodily demeanour (e.g. Oerton, 2004). After each home game they were required to change into smart lounge suits and join the fans in the corporate area of the stadium. They were expected to make polite conversation, sign autographs, agree to being photographed by any of the fans and applaud the after match speech made by one of the coaches. Contained within this embodied and appropriately attired activity there were also explicitly expressed rules about drinking alcohol and even controlled facial expressions as illustrated in the extracts below.

You are not supposed to frigging smile...I got told off once because we had lost and I
laughed at a joke at the bar afterwards...pathetic (Player)

If we lose we are expected to drink coke if we win we can have a beer (Player)

We can't be seen to celebrate if the fans are disappointed (Player)

We have to look sad and disappointed with ourselves - don't smile whatever you do until you get in the car and have driven out of the gates (laughter) (Player)

What the above extracts display for us are not the articulations we would expect from hard, un-reflexive, rugby players, rather, conceivably, illustrative of a lived experience of frustration at perhaps being expected to take it all too seriously beyond the pitch - beginning to encroach on what the players see as their personal spaces.

The embodied discipline also extends beyond the players. One of the coaching team was caught, laughing, on camera during a game when the Northern Knights were losing. The headlines in the local press criticised the coaches' attitude implied by the captured behaviour.

God you should have seen the photo I was throwing my head back laughing fit to bust - but it was at a joke about the other team, probably tension-trying not to think about how badly we were doing (Coach)

Now I try to stay deadpan- those cameras are everywhere. It is not just media everyone has a phone and will sell the photo (Coach)

It is apparent that within the gaze of the disciplinary 'other' these male workers are required to engage in self-surveillance work that produces the appropriately 'masculine' body while at the same time producing the appropriately deferential demeanour. 
It has been described above how rituals of discipline are apparently drawn upon to bring about the docile body. It is evident that the public domain (both on and off the field) requires particular embodied and emotional activities. In a local context, rugby players who are located in close proximity to the scrutiny and gaze of their audiences provide a knowing compliance to appropriate behaviour within the 'gaze'. For Foucault, and the sense that I am using 'the gaze' here, the observer impacts upon the observed without having to be physically present - simply through a perception of the existence of a judgemental observer. This will affect behaviour - including body-work behaviour and thus has something to say about performance too.

Finally, and perhaps in keeping with a requirement to be a real man and endure pain (Roderick et al, 2000), the players construct themselves as willing accomplices in this process.

See a weakness you work at it till its gone....(Player)

No-one can push you more than you push yourself....(Player)

You throw up on the line and run back on the pitch wiping the spit from your chin....bring it on (Player)

However, despite these heroic accounts of self-discipline, the male athletic identity appears to be threatened by possibilities of injury which may ultimately bring about the end of their careers. The players describe their awareness of these risks and present them as normalised, embodied, effects of their work in the extracts below.

I've been really unlucky with injuries, I've been out for like nearly three and half, four years, I'm injured now and broke my leg like eight weeks ago l've just got my pot off (Player)

There wouldn't be too many players that play these days that don't have injuries or have had injuries, it's probably been about since I was sixteen or seventeen I haven't woken up feeling fully, fully fine (Player)

I think most people carry injuries through their whole career (Player)

I think everyone knows now it's a profession and, you know, you've only got a short life in the game (Player)

Thus, despite all their best efforts to discipline and hone their bodies, willingly and in response to organized endeavours on their bodies, to be fit for purpose; it seems that the purpose itself is body damaging and this risk is taken for granted unquestioningly as part of the work. There is an inevitable and gradual erosion of bodily capital, in Bourdieu's terms, which renders the player less valuable, in organizational terms. They are increasingly less likely to be picked to play, thus they are eventually dropped from the team. Some players carry on playing by joining teams lower down the league tables until their late 30s when injury prevents them from playing altogether. Their career path is one which ends in increasing numbers of injuries and defeats but for some of them it is all they know that they are good at.

It was always part of my life, kept growing up and that's probably the only thing I was really born to do (Player)

In keeping with Wacquant's professional boxers, the players also talk about being a professional rugby player as a kind of possession, unable to resist it as a way of being. 
It is all I know (Player)

It's in my blood (Player)

\section{Discussion}

The study is explicitly about masculine bodies, who work at playing rugby which exemplifies a definite form of masculinity. It is not, however, argued that there is a single consistent image of masculinity; there are contradictory representations (see, for example, heroes played by Sean Connery, Arnold Schwarzenager and Woody Allen all providing competing arguments on how a man should be (Edley and Wetherell, 1996)). Contradictory and changing forms of masculinity have potential to undermine hegemonic forms over time (Mills, 1998). Thus, it is a contested terrain, an ideological battlefield in which men are both producers and products of the culture. Rather than hegemonic masculinity being a natural state or object invoked by stereotypical views, it is a complex interaction of structure, discourse and bodily activity - performed within a field, or habitus, that provide conditions of possibility for their enactment.

Although much of the training appears to present and amplify macho, heroic, attributes, the route towards this end requires subjugation to disciplinary processes imputed by others. For example, the measurement and weighing of the players appears to resonate with studies of female flight attendants who were also weighed during 'grooming checks' (Tyler and Abbott, 1998) to ensure they remained within an appropriate weight for performance. Much has been written about female bodies mostly with male bodies as comparator (Godfrey et al, 2012) and sometimes as a contrast (Simpson, 2011; Sinclair, 2005). What the study adds is an analysis of hyper-male bodies as also subdued, docile and disciplined. Their male-worker bodies are crafted and formed to be utilised for some economic (and personal) outcome (c.f. Mavin and Grandy, 2011), that ultimately ends in injury, defeat and failure. The study has illustrated how the discipline functions and what kinds of (newly crafted) male bodies get talked about.

It can be argued that, in comparison to the desirable body being crafted by the trainer and the willing participant, the un-worked upon masculine body is found to be lacking (in strength, discipline, routinized physical effort) and therefore, arguably, feminised (see Trethewey's (1999) nuanced account of the in-betweens of gender). The other against which the hyper-masculine body is contrasted is a gauge against which the new body is measured and is shown to be significantly weaker. In this regard Foucault's (1977) notion of normalization functions to relegate the un-worked on masculine bodies as inferior as weaknesses have been identified.

It is argued that gender is a legitimating practice for certain forms of structure (like patriarchy), (Connell, 1995) and that every context may have its own masculinity or masculinities. With reference to another venue for the production of the improved male-worker body, from civilian to military male, Godfrey et al's (2012) study of the military movie, Jarhead, described how inferior recruits were referred to as 'pussy' or 'bitch' - hardship being a method to find out 'if we have any bitch in you' (2012 p 554), the feminine serves to mark subordination. In the extract below the coach can be seen to use similar reference, but in the opposite direction towards a desirable hyper-masculine position. 
I've got a saying-you can't put the dog into somebody. I can't go to some of the players, who I know are not the toughest kids, you've got to do it (tackle hard), because it's just not in there but what I can do to some of my really bad lads I can say I want you to back off that little bit and they'll back off that little bit, so it's very difficult to put the dog inside somebody, no matter how hard you train them (Coach)

So it seems that 'the dog' in this instance may well be the opposite of the weaker 'bitch' as used in military language for inferior colleagues and signifies a hierarchy of (more) desirable masculine attributes. It appears that the trainers operate from a position of making real and material for the players what a professional rugby players' embodied attributes should be. They effectively position and discipline others' professional bodies. They produce an objectified bodily existence for the players, not in the same way as women experience objectification (Young, 1990), but with clear understandings for the consequences of not succumbing to the disciplinary regimes. What this shows more broadly is that male bodies are also subject to selfdisciplining and socially imposed rules revealing a male on male gaze reminding them that they are being evaluated. The undisciplined male body in this profession renders it wanting the talent required to succeed in the field. It is not suggested that this is similar to those artificial, arbitrary and power-laden cultural restrictions that limit women's progression, however it does begin to articulate how male bodies are and are not worked upon to become organized and fit for purpose. What this illustrates is the un-worked-upon male body as a work in progress by comparison with the hyper-male ideal.

I have considered how these bodies are disciplined into particular modes of being, drawing in part on Foucault's notions of docility - although perhaps what the players produce is more like a controlled aggression, or self-disciplined violence. Foucauldian accounts of docility may overplay the centrality of external and internal surveillance, while underplaying the role of the wider environment which conditions the players' embodiment (Kolkowitz, 2006). Bourdieu's theory of embodiment appears to offer a more agentic explanation of the evolution of appropriate bodies through habitus, which considers a wider location within class and social relations. While it is clear that Foucault's detailed conceptions of measurement, surveillance, repetition and physical routines of practice and abstinence aptly describe the world of a professional rugby player in training and performing - this does not mean that all rugby players are disciplined - there are a number of examples of ill-disciplined players on and off the field. Sporting disciplines produce winners and losers but mostly subjects who are 'respectfully fragmented' (Markula and Pringle, 2006: 47). That said, the study has provided an empirical exploration of how the bodies are rendered as fit for work while creating a capacity through changed posture, gait and performance for subsequent embodied performances. The role of rituals in disciplinary procedures was evident. It has been illustrated how alternative ways of being embodied co-exist even within one social field so the male worker body in this instance is called to differently legitimated regimes.

With regard to studies of workers' socialised bodies, work that appears to depend upon docility may depend in essence on workers' tacit and embodied skill and agency (Kolkowitz, 2006). Within the rugby players' work world there are differences around the kind of embodied tasks that are required. 'Play' makers who occupy positions at half back, hooker etc. are skilful interpreters of appropriate moves and responses within a game, whereas other players largely offer brute force and speed. Furthermore, the living embodied labour of rugby players includes a nuanced 
understanding of appropriate body work - too much aggression and penalties are given away, or the player is sent off, not enough aggression and the player is not physically competitive on the field. This resonates with assembly workers' differential ability to interpret and gesture to colleagues within what appears to be a routine series of fragmented practices (Durand and Hatzfield, 2003), the workforce is not homogenous, nor entirely explainable through Foucauldian analysis nor entirely predictable as a response to habitus.

Thus, both docility and hyper-masculine performances are available and likely to appear from time to time. It is apparent, however, that within the more stereotypically understood macho environment of the rugby player, locally enacted and closely monitored bodily practices are more akin to those described by women who feel the male gaze upon them while aspiring towards being accepted in a male-dominated work environment. Among many other studies Trethewey (1999) was an early theorist to identify how socio-historic constructions of femininity are practised by: diet and exercise regimes, comportment, gesture, movement and other non-verbal behaviours which render women's bodies docile. These activities resonate with our findings about the rugby players' practices. They have political implications for the participants too, as their focus on producing the desirable body does not incline them to look at, or question, the material and political circumstances of their lives and the end of their playing career is rarely considered.

However, it can be argued that by saying 'it's all I know', 'it's in the blood' and similar expressions - a speaker may be constructing lack of agency in the light of the (apparently) damaging career they have (not) selected. Thus, in their accounts of their selves the rugby players' talk can be interpreted to include elements of resistance. What I mean by this is, rugby players appear to draw on particular subject positions to re-write their selves - or, more accurately, re-write their agency. They are accepting, yet denying (as not something they are choosing to do) and at the same time re-writing the subject position offered. But, rather than producing the maverick, or evidently resisting, worker they craft a position of helplessness which makes them un-accountable and therefore in a position that is epistemologically privileged. They are not attributing their career choice as something imposed and regulated by an employer, rather it is spoken about as if it is something they must do, rather like Wacquant's boxers 'a kind of possession'. That said, we also see how this results in the legitimization and reproduction of the material and political circumstances of their lives.

This study of professional rugby players highlights an embodied work experience that brings to view the worked upon masculine body - crafted for commercial gain. The machismo of the environment as stereotypically understood has been revealed to illustrate particular kinds of masculinity as subject to the patriarchal gaze. This offers a challenge to scholars of other work environments to question ideas around gendered embodiment routines and practices that commodify individuals as living capital and offers some ideas to enquire into accepted notions of masculinities in the work place. Of course there are differences between different professional sports, whose participants may occupy positions in different class systems and who may attract higher salaries for longer playing careers. These social, relational and capital processes will be having some impact on versions of masculinities that are deemed 
as more appropriate in their contexts - but that could be the subject of future research.

It is relevant to consider, therefore, that it is not just women who 'internalize the panoptical gaze of the male connoisseur' (Bartky, 1988 p 72), rugby players and other men also live their lives as seen by an anonymous patriarchal other.

\section{Concluding Comments}

By looking at the masculine body as disciplined and gendered the study contributes to an exploration of male worker bodies, called for by earlier scholars (e.g. Edley and Wetherell, 1996; Gullette, 1997, Trethewey, 1999; 2000). In the study I have explored how bodies become organized, how they are worked upon and become fit for work. The body that is invoked in order to do the work of a professional sports person is a docile and disciplined one that is mostly useful for the organization. However, it is clear that this re-organizing of surveillance and control around masculinities provides a space into which 'other' masculinities are rendered weaker. Furthermore, the ultimate temporality of this endeavour will end in failure (loss of form) or injury - an unfit fitness for a role being occupied by younger players. It has been demonstrated that; constant scrutiny and measurement of the body and of performances both on and off the pitch lead to more feminised accounts of bodily control mechanisms of; appropriate deference, facial expression and non-verbal control. These practices illustrate a kind of masculinity in operation which contrasts with the desirable, heroic, macho, male; that of the subdued, disciplined and docile performer of gender. It may be argued, from a feminist perspective, that this performance actually demonstrates a male prerogative to be able to choose to do this from a position of power. As the female author of the work, taking on the side (gaze) of the other, the docile acceptance of powerful regimes of control is all too readily recognisable, but not always of my choosing. That said, how masculinities are performed is an under researched area in organization studies and this study may lead to further investigation and a deconstruction of hegemonic understanding of maleness as a given. 


\section{References}

Balsamo A (1996) Technologies of the gendered body. Durham NC: Duke University.

Bartky SL (1988) Foucault, femininity and the modernization of patriarchal power. In I Diamond and L. Quinby (eds.) Feminism and Foucault: Reflections on resistance. Boston: Northeastern University Press, 61-86.

Bordo S (1989) The body and the reproduction of femininity. In Jaggar A and Bordo S (Eds.) Gender, body, knowledge. New Brunswick, NJ: Rutgers University Press. Bourdieu P (1977) Outline of a theory of practice. Cambridge: Cambridge University Press.

Bourdieu P (1984) Distinction: A social critique of the judgement of taste. London: Routledge.

Bourdieu P (1990) The logic of practice (trans. Nice) Cambridge: Polity Press:

Bourdieu $\mathrm{P}$ and Wacquant $\mathrm{L}$ (1992) An invitation to reflexive sociology. Cambridge: Polity Press.

Braverman H (1974) Labour and Monopoly Capital: The Degradation of work in the Twentieth Century. New York: Monthly Review Press.

Brewis J and Linstead S (2000) Sex, work and sex work: Eroticizing organization. London: Routledge.

Coakley J (2004) Sports in society: Issues and controversies. $8^{\text {th }}$ Edition. London: McGraw-Hill.

Connell RW (1995) Masculinities. St. Leonards: Allen \& Unwin.

Connell RW (2000) The men and the boys. Cambridge: Polity Press.

Crossley N (2001) The social body: Habit, identity and desire. London: Sage.

Daly A (1995) Done into dance: Isadora Duncan in America. Bloomington: Indiana University press.

Durand JP and Hatzfield N (2003) Living labour: Life on the line at Peugeot, France. Basingstoke: MacMillan-Palgrave.

Edley N and Wetherell M (1996). Masculinity, power and identity. In Mac an Ghaill M (Ed.) Understanding Masculinities: social relations and cultural arenas. Buckingham, U.K.: Open University Press. 97-114.

Ezzell M (2009) Barbie dolls" on the pitch: Identity work, defensive othering and inequality in women's rugby. Social Problems, 56(1), 111-131.

Foucault M (1976) The history of sexuality Vol 1, An introduction (trans R. Hurley) New York: Pantheon.

Foucault M (1977) Discipline and Punish: The birth of a prison (trans A. Sheridan) London: Allen Lane.

Foucault M (1984) The care of the self: Vol 3 The history of sexuality (trans R.

Hurley) New York: Vintage.

Godfrey R, Lilley S and Brewis J (2012) Biceps, bitches and borgs: Reading Jarhead's representation of the construction of the (masculine) military body. Organization, 33(4), 541-562.

Gray A (1983) The Jones men: 100 New Zealand men talk about their lives.

Wellington: Reed.

Gullette MM (1997) Declining to decline: Cultural combat and the politics of midlife. Charlottesville, VA: University of Virginia Press.

Harman C (2009) Zombie Capitalism: Global Crisis and the Relevance of Marx. Chicago ILL: Haymarket Books.

Haynes K (2012) Body beautiful? Gender, identity and the body in professional 
services firms. Gender, Work and Organization, 19(5), 489-507.

Howe PD (2001) An ethnography of pain and injury in professional rugby union. International Review for the Sociology of Sport, 38(3), 289-303.

Klinenberg E (2002) Bodies that don't matter: Death and dereliction in Chicago. In Scheper-Hughes N and Wacquant L (Eds.) Commodifying Bodies. London: Sage, 121-136.

Knoppers A and Anthonissen A (2005) Male athletic and managerial masculinities: Congruencies in discursive practices? Journal of Gender Studies, 14(2), 123-135.

Kolkowitz C (2006) Bodies at Work. London: Sage.

Linstead S (1995) Averting the gaze: Gender and power on the perfumed picket line. Gender, Work and Organization, 2(4), 192-206.

Markula P and Pringle R (2006) Foucault, sport and exercise: Power, knowledge and transforming the self. Abingdon: Routledge.

Mavin S and Grandy G (2011) Doing gender well and differently in dirty work. The case of exotic dancing. Gender, Work and Organization, published online:

10.1111/j.1468-432.2011.00567.

McLeod J (2005) Feminists re-reading Bourdieu: Old debates and new questions about gender habitus and gender change. Theory and Research in Education, 3(1), 11-30.

McNay L (2000) Gender and agency: Reconfiguring the subject in feminist and social theory. Cambridge: Polity Press.

Messner M (2002) Taking the field: Women, men and sports. Minneapolis: University of Minnesota Press.

Mills A (1998) Cockpits, hangars, boys and galleys: Corporate masculinities and the development of British Airways. Gender, Work and Organization, 5(3), 172-188.

Morris G (2001) Bourdieu, the body and Graham's post-war dance. Dance

Research, 19(2), 52-82.

Oates JC (1987) On boxing. Garden City: Doubleday.

Oerton S (2004) Bodywork boundaries: Power, politics and professionalism in therapeutic massage. Gender, Work and Organization, 11, 544-565.

Pringle R (2001) Competing discourses: Narratives of a fragmented self, manliness and rugby union. International Review for the Sociology of Sport, 36(4) 425-439.

Roderick M Waddington I and Parker G (2000) Playing hurt: Managing injuries in English Professional Football. International Review of the Sociology of Sport, 35(2), 165-80.

Scheper-Hughes N and Wacquant L (2002) Commodifying Bodies. London: Sage. Simpson R (2011) Men discussing women and women discussing men: Reflexivity, transformation and gendered practice in the context of nursing care. Gender, Work and Organization, 18, 377-398.

Sinclair A (2005) Body possibilities in leadership, Leadership, 1, 387-406.

Storey D (1960) This Sporting Life. London: Longmans.

Thompson JB (1991) Editor's introduction in P Bourdieu Language and symbolic power. Cambridge: Cambridge Polity Press (1-31).

Trethewey A (1999) Disciplined bodies: Women's embodied identities at work.

Organization Studies, 20(3), 423-450.

Trethewey A (2000) Revisioning control: A feminist critique of disciplined bodies. In Buzzanell P (Ed.) Rethinking organizational and managerial communication from feminist perspectives. Thousand Oaks, CA: Sage, 107-127.

Tyler M and Abbott P (1998) Chocs away: Weight watching in the contemporary airline industry. Sociology, 32, 433-450. 
Van Maanen J (2011) Tales of the field: On writing ethnography $2^{\text {nd }}$ edition. London: University of Chicago Press.

Wacquant L (1995) Pugs at work: Bodily capital and bodily labour among professional boxers. Body and Society, 1(1), 65-93.

Wacquant L (2004) Body and Soul: Notebooks of an apprentice boxer. New York:

Oxford University Press.

Wacquant $L$ (2011) Habitus as topic and tool: Reflections on becoming a prize fighter. Qualitative Research in Psychology, 8, 81-92.

Wainwright S and Turner B (2006) Just crumbling to bits? An exploration of the body, ageing, injury and career in classical ballet dancers. Sociology, 40(2): 237-255.

Watson J (2000) Male bodies: Health, culture and identity. Buckingham: Open University Press.

West C and Fenstermaker S (1995) Doing difference. Gender and Society, 9, 8-37. Young IM (1990) Throwing like a girl and other essays in Feminist philosophy and social theory. Bloomington IN: Indiana University Press.

Young K White P and McTeer W (1994) Body Talk: Male Athletes Reflect on Sport, Injury, and Pain, Sociology of Sport, 175-94. 